\title{
Evaluation of Yeast Cell Wall on The Performance of Broiles Fed Diets With or Without Mycotoxins
}

Author(s)
Santin $E^{1}$
Paulillo $A^{2}$
Nakagui $L S O^{2}$
Alessi $A C^{2}$
Maiorka $A^{1}$
1 Universidade Federal do Paraná - UFPR.
2 Faculdade de Ciências Agrárias e
Veterinárias - Unesp.

\section{Mail Address}

Elizabeth Santin

Departamento de Medicina Veterinária

Setor de Ciências Agrárias / UFPR

Rua dos Funcionários, 1540

Juveve

80.035-050. Curitiba, PR, Brazil

\section{Keywords}

Aflatoxin, Ochratoxin, Yeast cell wall, broilers, performance.

\section{Acknowledgments}

The authors thank Fundação de Amparo à Pesquisa do Estado de São Paulo. Proc. n. 99/ 12952-7 for their financial support.

\section{ABSTRACT}

This experiment aimed at evaluating the effects of the interactions between aflatoxin (500 or 250 ppb) and ochratoxin (500 or 250 ppb), and the possible benefits of adding yeast cell wall to prevent the effects of these mycotoxins in broiler chickens. Relative organ weight gain and live performance were evaluated at 21 and 42 days of age. Results indicated that at the levels of mycotoxins included in the experimental diets, ochratoxin reduced feed intake and body weight gain, and aflatoxin only affect feed intake of 21-day-old birds. No interaction was observed between aflatoxin and ochratoxin at the levels used in experimental study. Yeast cell wall did not significantly reduced the deleterious effects of ochratoxins. No significant differences were observed in relative organ weight gain. Yeast cell wall improved feed conversion ratio when birds were fed either contaminated or noncontaminated feeds.

\section{INTRODUCTION}

Mycotoxins are toxic substances produced by fungi that commonly grow in cereals used in animal feeds and human food (Santin et al., 2000). Fungi infestation and the production of mycotoxins may occur any time in a cereal mass. In general, the interaction between fungi species and variations in temperature and moisture promotes a mixture of different mycotoxins in the stored grain (Ramakrishna et al., 1996).

Huff \& Doerr (1981) reported that aflatoxin and ochratoxin can be found as simultaneous contaminants of feed ingredients and finished feed, and the effect of the synergic action of these two mycotoxins on growth rate was far greater than the sum of the individual toxicities of these mycotoxins. According with these authors, the synergism between aflatoxin and ochratoxin A significantly decreased growth rate and numerically increased mortality, demonstrating the enhanced toxicity of contaminated feed.

Recently, the most promising and practical approaches to counteract mycotoxins are the use of adsorbents. However, although several studies showed that aluminosilicates can reduce the effects of aflatoxins, due to their binding capacity (Phillips et al., 1988; Kubena et al., 1990), these adsorbents cannot alleviate the harmful effects of ochratoxin (Santin et al., 2002). This is probably due to the variation in the structure of adsorbents and of mycotoxins. A study of Huff et al. (1992) suggested that when aflatoxin is found to be the only mycotoxin present in the diet, it may be cost effective to add aluminosilicates to the diet to minimize the effects of the problem. However, if ochratoxin A is present, aluminosilicates have little effect on the toxicity of this mycotoxin, and the proportion of aflatoxin biologically available to the animal may interact with ochratoxin, resulting in a little benefit from the use of aluminosilicates. 
Santin E, Paulillo AC, Nakagui LSO, Alessi AC, Maiorka A
On the other hand, a live yeast, Saccharomyces cerevisiae, was found to alleviate the adverse effects of aflatoxicosis in poultry (Stanley et al., 1993). Its beneficial effects are attributed to the composition of its cell wall. The objective of the present study was to evaluate the effect of the interaction between aflatoxin and ochratoxin on relative organ weight and performance of broilers, and the effects of yeast cell wall (SCCW) to counteract these mycotoxins.

\section{MATERIAL AND METHODS}

\section{Experimental birds and diets}

Six hundred and forty day-old Cobb male broilers were used. Birds were fed a balanced diet, based on corn and soybean meal, formulated according to the recommendations of the National Research Council (1994). The corn used was free from aflatoxin, ochratoxin, and zearalenone, as determined by thinlayer chromatography (Soares \& Rodriguez-Amaya, 1989). Birds were submitted to similar management as that practiced in commercial flocks.

\section{Mycotoxin and Yeast cell wall}

Aflatoxin was produced by the fermentation of rice with Aspergillus parasiticus, strain NRRL 2999, according to West et al. (1973). Ochratoxin was produced by the fermentation of wheat with Aspergillus ochraceus, strain NRRL 3174, according to Manning \& Wyatt (1984). After fermentation, wheat and rice were dried in an oven at $100{ }^{\circ} \mathrm{C}$ for 12 hours, and ground. Ochratoxin $A$ and aflatoxin levels were analyzed by thin-layer chromatography, according to the technique described by Soares \& Rodriguez-Amaya (1989).

Saccharomyces cerevisiae var. Calsberg was cultivated in simple agar. After growth, it was replicated in liquid peptonized water with $2 \%$ of dextrose and incubated at $37{ }^{\circ} \mathrm{C}$ for 48 hours. Then, the solid phase was separated by centrifugation at 3000 x for 30 min, and lyophilized to be incorporated in feed.

The inocula (500 ppb or $250 \mathrm{ppb}$ of aflatoxin and ochratoxin, and $0.1 \%$ of yeast cell wall) were weekly mixed into the feed, as indicated by each treatment, from the first day until the end of the trial (1 to 42 days).

\section{Experimental design}

A randomized experimental design with a factorial arrangement $(3 \times 3 \times 2)$ incomplete block with missing cells was used, with 640 birds distributed into eight groups of 80. Group 1 did not receive either mycotoxin
Evaluation of Yeast Cell Wall on The Performance of Broiles Fed Diets With or Without Mycotoxins

or yeast cell wall in the diet, Group 2 was fed 500 ppb of aflatoxin in diet, Group 3 was fed a diet containing 500 ppb of ochratoxin, Group 4 was fed a diet containing $250 \mathrm{ppb}$ of aflatoxin and $250 \mathrm{ppb}$ of ochratoxin, Group 5 was fed a diet containing 0.1\% yeast cell wall, Group 6 was fed a diet containing 500 ppb of aflatoxin and $0.1 \%$ yeast cell wall, Group 7 was fed a diet containing 500 ppb of ochratoxin and $0.1 \%$ yeast cell wall, and Group 8 was fed a diet containing 250 ppb aflatoxin, 250 ppb ochratoxin and $0.1 \%$ yeast cell wall. Data were submitted to analysis of variance.

\section{Necropsy and morphometric analysis of the organs}

On days 21 and 42 of the experimental period, eight birds from each group were slaughtered by cervical dislocation to perform macroscopic observation of the bursa of Fabricius, liver, and kidney. These organs were immediately dissected and individually weighed. Weights were expressed as a percentage of body weight, thus obtaining the relative weight of each organ.

\section{Performance analysis}

Birds and residual feed were weighed at the beginning and end of each experimental stage (initial stage: 1 to 21 day and final stage: 22 to 42 days). Feed conversion ratio was obtained by dividing total feed intake by weight gain of each pen added to the weight of dead birds.

\section{RESULTS AND DISCUSSION}

Mycotoxins may cause significant losses to poultry industry due to reduced performance and health problems in the exposed birds as was observed in the present study. The results in Table 1, 2, and 3 show that ochratoxin in the diet significantly decreased feed intake and weight gain as compared to the control group. Birds exposed to ochratoxin during initial stage (1 to 21 days), final stage ( 22 to 42 days), or in total experimental period ( 1 to 42 days) had lower average feed intake and weight gain $(P<0.05)$. Prior et al. (1980) also showed performance reduction using the same ochratoxin levels in broilers. However, aflatoxin caused a significant $(P=0.040)$ decrease in feed intake at 21 days (Table 1). This mycotoxin did not influence other performance parameters at 21 or 42 days (Tables 1,2 and 3), which is probably due to the lower levels of this mycotoxin used in the present study. It is known that aflatoxin level should be of at least 1 ppm to affect 
Santin E, Paulillo AC, Nakagui LSO, Alessi AC, Maiorka A
Evaluation of Yeast Cell Wall on The Performance of Broiles Fed Diets With or Without Mycotoxins

\begin{tabular}{|c|c|c|c|c|c|}
\hline Aflatoxin(ppb) & Ochratoxin(ppb) & $\operatorname{SCCW}^{*}(\%)$ & Feed intake (g) & Weight gain (g) & Feed:gain(g/g) \\
\hline 0 & 0 & 0 & 1,136 & 694 & 1.642 \\
\hline 0 & 500 & 0 & 1,071 & 667 & 1.606 \\
\hline 500 & 0 & 0 & 1,063 & 699 & 1.520 \\
\hline 250 & 250 & 0 & 1,010 & 639 & 1.579 \\
\hline 0 & 0 & 0.1 & 1,136 & 723 & 1.575 \\
\hline 0 & 500 & 0.1 & 1,040 & 660 & 1.578 \\
\hline 500 & 0 & 0.1 & 1,078 & 726 & 1.487 \\
\hline \multirow[t]{15}{*}{250} & 250 & 0.1 & 1,019 & 640 & 1.596 \\
\hline & & & & Main effects & \\
\hline & Aflatoxin (+) & & 1,047 & 676 & 1.546 \\
\hline & Aflatoxin (-) & & 1,096 & 686 & 1.600 \\
\hline & Ochratoxin (+) & & 1,035 & 651 & 1.590 \\
\hline & Ochratoxin (-) & & 1,103 & 710 & 1.556 \\
\hline & $\operatorname{sccW}(+)$ & & 1,069 & 675 & 1.559 \\
\hline & $\operatorname{SCCW}(-)$ & & 1,070 & $\begin{array}{c}687 \\
\text { Probabilities }\end{array}$ & 1.587 \\
\hline & Aflatoxin (A) & & 0.040 & 0.417 & 0.195 \\
\hline & Ochratoxin (O) & & 0.011 & 0.000 & 0.419 \\
\hline & $\operatorname{sCCW}(\mathrm{SC})$ & & 0.948 & 0.313 & 0.501 \\
\hline & $A \times 0$ & & 0.629 & 0.251 & 0.235 \\
\hline & $A \times S C$ & & 0.586 & 0.924 & 0.636 \\
\hline & $\mathrm{O} \times \mathrm{SC}$ & & 0.701 & 0.214 & 0.522 \\
\hline & $A \times O \times S C$ & & 0,808 & 0,845 & 0,948 \\
\hline
\end{tabular}

SCCW - Cell wall of Saccharomyces Cerevisiae.

\begin{tabular}{|c|c|c|c|c|c|}
\hline Aflatoxin(ppb) & Ochratoxin(ppb) & $\operatorname{SCCW}^{*}(\%)$ & Feed intake $(\mathrm{g})$ & Weight gain (g) & Feed:gain(g/g) \\
\hline 0 & 0 & 0 & 3,555 & 1,781 & 1.995 \\
\hline 0 & 500 & 0 & 3,329 & 1,658 & 2.008 \\
\hline 500 & 0 & 0 & 3,543 & 1,717 & 2.063 \\
\hline 250 & 250 & 0 & 3,405 & 1,665 & 2.045 \\
\hline 0 & 0 & 0.1 & 3,437 & 1,813 & 1.903 \\
\hline 0 & 500 & 0.1 & 3,459 & 1,700 & 2.034 \\
\hline 500 & 0 & 0.1 & 3,452 & 1,781 & 1.941 \\
\hline \multirow[t]{15}{*}{250} & 250 & 0.1 & 3,261 & 1,673 & 1.949 \\
\hline & & & & Main effects & \\
\hline & Aflatoxin (+) & & 3,445 & 1,709 & 1.999 \\
\hline & Aflatoxin (-) & & 3,444 & 1,737 & 1.985 \\
\hline & Ochratoxin (+) & & 3,363 & 1,674 & 2.009 \\
\hline & Ochratoxin (-) & & 3,496 & 1,773 & 1.976 \\
\hline & $\operatorname{sccW}(+)$ & & 3,402 & 1,741 & 1.957 \\
\hline & $\operatorname{sccW}(-)$ & & 3,457 & $\begin{array}{c}1,705 \\
\text { Probabilities }\end{array}$ & 2.028 \\
\hline & Aflatoxin (A) & & 0.636 & 0.240 & 0.665 \\
\hline & Ochratoxin (O) & & 0.041 & 0.000 & 0.319 \\
\hline & $\operatorname{sCCW}(\mathrm{SC})$ & & 0.375 & 0.140 & 0.042 \\
\hline & $A \times 0$ & & 0.620 & 0.436 & 0.255 \\
\hline & $A \times S C$ & & 0.325 & 0.980 & 0.258 \\
\hline & $\mathrm{O} \times \mathrm{SC}$ & & 0.437 & 0.650 & 0.285 \\
\hline & $A \times O \times S C$ & & 0.234 & 0.508 & 0.492 \\
\hline
\end{tabular}

SCCW - Cell wall of Saccharomyces Cerevisiae.

bird performance under experimental conditions (Santin et al., 2003).

In the present study, no significant $(P>0.05)$ interaction between aflatoxin and ochratoxin was observed, contrary to the reports of Huff \& Doerr (1981) and Huff et al. (1992), probably due to the lower levels of mycotoxins used in the present study as compared to those studies.
The addition of SCCW to the diet containing mycotoxins did not minimize the deleterious effects of ochratoxin, but improved feed conversion ratio in birds fed diets with or without mycotoxin during the final stage (22 to 42 days) and total experimental period (1 to 42 days). A recent study from Santin et al. (2001) showed that SCCW improved intestinal mucosa parameters, and suggested that this might be the 
Santin E, Paulillo AC, Nakagui LSO, Alessi AC, Maiorka A
Evaluation of Yeast Cell Wall on The Performance of Broiles Fed Diets With or Without Mycotoxins

\begin{tabular}{|c|c|c|c|c|c|}
\hline Aflatoxin(ppb) & Ochratoxin(ppb) & $\operatorname{SCCW}^{*}(\%)$ & Feed intake $(g)$ & Weight gain (g) & Feed:gain $(g / g)$ \\
\hline 0 & 0 & 0 & 4,691 & 2,475 & 1.896 \\
\hline 0 & 500 & 0 & 4,400 & 2,325 & 1.906 \\
\hline 500 & 0 & 0 & 4,600 & 2,417 & 1.905 \\
\hline 250 & 250 & 0 & 4,415 & 2,304 & 1.916 \\
\hline 0 & 0 & 0.1 & 4,573 & 2,536 & 1.807 \\
\hline 0 & 500 & 0.1 & 4,500 & 2,360 & 1.906 \\
\hline 500 & 0 & 0.1 & 4,530 & 2,506 & 1.808 \\
\hline \multirow[t]{15}{*}{250} & 250 & 0.1 & 4,280 & 2,313 & 1.850 \\
\hline & & & & Main effects & \\
\hline & Aflatoxin (+) & & 4,458 & 2,385 & 1.870 \\
\hline & Aflatoxin (-) & & 4,541 & 2,424 & 1.876 \\
\hline & Ochratoxin (+) & & 4,399 & 2,325 & 1.854 \\
\hline & Ochratoxin (-) & & 4,600 & 2,483 & 1.891 \\
\hline & $\operatorname{sccW}(+)$ & & 4,471 & 2,429 & 1.903 \\
\hline & SCCW (-) & & 4,528 & $\begin{array}{c}2,380 \\
\text { Probabilities }\end{array}$ & 1.843 \\
\hline & Aflatoxin (A) & & 0.243 & 0.196 & 0.811 \\
\hline & Ochratoxin (O) & & 0.008 & 0.000 & 0.129 \\
\hline & $\mathrm{sCCW}(\mathrm{SC})$ & & 0.419 & 0.106 & 0.019 \\
\hline & $A \times O$ & & 0.789 & 0.870 & 0.648 \\
\hline & $A \times S C$ & & 0.495 & 0.985 & 0.360 \\
\hline & $\mathrm{O} \times \mathrm{SC}$ & & 0.577 & 0.375 & 0.169 \\
\hline & $A \times O \times S C$ & & 0.331 & 0.643 & 0.474 \\
\hline
\end{tabular}

SCCW - Cell wall of Saccharomyces Cerevisiae.

explanation for the improvement of the performance of broilers supplemented with SCCW in that report. In fact, the yeast cell wall used in the present study was not efficient in alleviating the effects of ochratoxicosis. However, it improved feed conversion of birds fed diets with or without mycotoxins, suggesting that the effect of the SCCW used was probably not due to its role as mycotoxin adsorbent, but as a supplement that improved feed conversion ratio. Yeast cell wall usually contains mannan oligosaccharides, and some reports showed that the use of these compounds improves feed conversion ratio(Savage \& Zakrzewska, 1997, Fritts \& Waldroup, 2003).

Although it was reported that ochratoxin and aflatoxin cause increase in relative liver and kidney weight in poultry (Huff \& Doerr, 1981), the present study did not show any differences in relative organ weight among the experimental groups. A possible explanation for this finding may be the relatively higher mycotoxin levels used by Huff \& Doerr (1981) as compared those used in the present study.

\section{CONCLUSIONS}

It may be suggested that ochratoxin causes losses in performance of broilers, and that SCCW was not efficient in reducing the losses caused by this mycotoxin. However, SCCW may be used as a supplement to improve feed conversion ratio in broilers.

\section{REFERENCES}

Fritts CA, Waldroup PW. Evaluation of Bio-Mos ${ }^{\circledR}$ mannan oligosaccharides as a replacement for growth promoting antibiotics in diet for turkeys. International Journal of Poultry Science 2003; 2 (1):19-22.

Huff WE, Doerr J. Synergism between aflatoxin and ochratoxin A in broiler chickens. Poultry Science 1981; 60:550-555.

Huff WE, Kubena LR, Harvey RB. Progression of ochratoxicosis in broiler chickens. Poultry Science 1992; 71:64-69.

Kubena LF, Harvey RB, Phillips TD, Corrier DE, Huff WE. Diminution of aflatoxicosis in growing chickens by dietary addition of a hydrated sodium calcium aluminosilicate. Poultry Science 1990; 69:727-735.

Manning RO, Wyatt RD. Toxicity of Aspergillus ochraceus contaminated wheat and different chemical forms of ochratoxin A in broiler chicks. Poultry Science 1984; 63:458-465.

National Research Council, Nutrient requirements of poultry. $9^{\text {th }}$ rev. ed. Washington: National Academic Press; 1994.

Phillips TD, Kubena LF, Harvey RB, Taylor DR, Heidelbaurgh NH. Hydrated sodium calcium aluminosilicate: a high affinity sorbent for aflatoxin. Poultry Science 1988; 67:243-247.

Prior MG, O'Neil JB, Sisodia CS. Effects of ochratoxin A on growth response and residues in broilers. Poultry Science 1980; 59:12541257.

Ramakrishna N, Lacey J, Smith JE. Aspergilus flavus colonization and aflatoxin $B$ formation in barley grain during interactions with other fungi. Mycopathologia 1996; 136:53-63. 


\section{Santin E, Paulillo AC, Nakagui LSO, Alessi AC, Maiorka A}

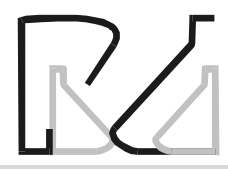

Evaluation of Yeast Cell Wall on The Performance of

Broiles Fed Diets With or Without Mycotoxins

Santin E, Maiorka A, Krabbe EL, Paulillo AC, Alessi AC. Effect of Hydrated sodium calcium aluminosilicates on the prevention of the toxic effects of ochratoxin. Journal of Applied Poultry Research $2002 ; 11: 22-28$.

Santin E, Maiorka A, Macari M, Grecco M, Sanchez JC, Okada TM, Myasaka AM. Performance and Intestinal Mucosa Development in Broiler Chickens Fed Ration Containing Saccharomyces Cerevisiae Cell Wall. Journal of Applied Poultry Research 2001; 10:236-244.

Santin E, Paulillo AC, Maiorka A, Nakagui LSO, Macari M, Fischer da Silva AV, Alessi AC. Evaluation of the efficacy of Saccharomyces cerevisiae cell wall to ameliorate the toxic effects of aflatoxin in broilers. International Journal Poultry Science 2003; 2(5):in press.

Santin E. Micotoxicoses. In: Berchieri Jr A, Macari M., editor. Doenças das aves. Campinas: Facta; 2000. p.379-388.

Savage TF, Zakrzewska El. The performance of male turkeys fed a starter diet containing a mannan oligosaccharides. Zootechnia International 1997; 20:30-32.

Soares LM, Rodriguez-Amaya DB. Survey of aflatoxins, ochratoxin A, Zearalenona, and sterigmatocystins in some Brazilian foods by using multi - toxin thin-layer chromatographic method. Journal Association Official Analytical Chemistry 1989; 72:22-26.

Stanley VG, Ojo R, Woldesenbet S, Hutchinson DH. The use of Saccharomyces cerevisiae to suppress the effects of aflatoxicosis in broiler chicks. Poultry Science 1993; 72:1867-1872.

West S, Wyatt RD, Hamilton PB. Improved Yield of Aflatoxin by Incremental Increases of Temperature. Applied Microbiology 1973; 25:1018-1019. 